\title{
El peronismo y sus tradiciones políticas en los años de la proscripción. Las celebraciones del Primero de Mayo y del 17 de Octubre en la Argentina entre 1962 y 1966
}

\section{Peronism and its political traditions in the years of the proscription. The celebrations of May Day and October 17 in Argentina between 1962 and 1966}

\author{
Andrés Nicolás Funes \\ Centro de Estudios Sociopolíticos. Escuela Interdisciplinaria de Altos Estudios \\ Sociales/Universidad Nacional de San Martín/CONICET, Argentina \\ funes.andres.n@gmail.com \\ https://orcid.org/0000-0001-6612-8718
}

Recibido: 30/11/2020

Aceptado: 15/04/2021

Cómo citar este artículo: FUNES, Andrés Nicolás (2021). El peronismo y sus tradiciones políticas en los años de la proscripción. Las celebraciones del Primero de Mayo y del 17 de Octubre en la Argentina entre 1962 y 1966. Pasado y Memoria. Revista de Historia Contemporánea, (23), pp. 307-332, https:// doi.org/10.14198/ PASADO2021.23.13

\section{Resumen}

El presente artículo estudia las tradiciones políticas del peronismo entre 1962 y 1966 en Argentina. Para ello, se analiza el sentido otorgado a dos celebraciones de su espacio político: el «Primero de Mayo» y el «17 de Octubre». Se conciben las tradiciones políticas como un conjunto selectivo de valores y prácticas, transmitidas desde el pasado, pero desplazadas y disputadas en el presente. A través de periódicos nacionales y provinciales se examinan estas conmemoraciones, entendiendo que los rituales políticos enlazan a los participantes con el pasado, les dan sentido de pertenencia y escenifican jerarquías. Durante los años sesenta argentinos, si bien la proscripción 
al peronismo seguía vigente, los gobiernos civiles de Arturo Frondizi y Arturo Illia ofrecieron espacios para que partidos de filiación peronista se insertaran en el sistema político-institucional argentino. No así Perón. Además de intensificar los conflictos internos, esas tentativas tuvieron un cierto impacto en el sentido otorgado a ambas celebraciones rituales peronistas.

Palabras clave: Peronismo; Tradiciones políticas; Rituales políticos; Años sesenta; Argentina; 1 de Mayo; 17 de Octubre.

\begin{abstract}
This paper studies the political traditions of Peronism in Argentina from 1962 to 1966, by analyzing the meaning given to two major celebrations connected with political issues: «May $1^{\text {st }}$, and «October $17 »$. Political traditions are conceived as a selective set of values and practices, transmitted from the past, though displaced and disputed in the present. These commemorations are examined on the basis of national and local newspapers, taking asuming that political rituals link participants with the past, give them a sense of belonging, and embody hierarchies. In the Argentine sixties, although the ban on Peronism was still active, the civil governments of Arturo Frondizi and Arturo Illia offered spaces for Peronist parties to join the Argentine political-institutional system. Not so Perón. In addition to intensifying internal conflict, those attempts had some impact on the meanings given to both Peronist ritual celebrations.
\end{abstract}

Keywords: Peronism; Political Traditions; Political Rituals; Early Sixties; Argentina; May $1^{\text {st }} ;$ October 17 th.

Agradecimientos: El autor quiere agradecer los comentarios de las y los evaluadores. Sus observaciones permitieron enriquecer este artículo. Como todo oficio, mucho de la escritura académica se aprende de la experiencia práctica. Sin embargo, como ha sugerido la gran pedagoga argentina María Cristina Davini, el oficio no es solo eso. También involucra un conjunto articulado de reglas y criterios de acción práctica legítima. En esa tensa relación entre la práctica y las reglas se desarrolló este trabajo.

\title{
Introducción
}

En El 18 Brumario de Luis Bonaparte, Karl Marx acuñó una de sus frases más conocidas: «La tradición de todas las generaciones muertas oprime como una pesadilla el cerebro de los vivos» ([1852] 2003: 15). Ello llevaba a los hombres, según el autor, a «volver a la vida» viejas nociones de una «tradición» cuando intentaban crear algo nuevo. Sin embargo, esos nombres, consignas e ideas redivivas no eran más que un remedo de lo que fueron en realidad. Marx acertó respecto a la forma en que operan las tradiciones. Antes que un conjunto de elementos pasivamente transmitidos a la posteridad, las tradiciones acosan la interpretación que las sucesivas generaciones hacen de su presente y de su 
futuro. No obstante, están lejos de ser un traspaso liso y llano. Las tradiciones se encuentran plagadas de baches, sinuosos meandros, parches, nuevos sentidos anudados, en definitiva, de una serie de olvidos y extravíos, donde lo que vuelve a la memoria, como ha dicho Yosef Hayim Yerushalmi (1989), se encuentra todo metamorfoseado.

Las tradiciones políticas son un conjunto selectivo e inventado de valores y prácticas, transmitidas desde el pasado, pero releídas y trabajadas desde el presente, que informan a los miembros de un grupo sobre algunos modos a través de los cuales pensar, actuar y sentir ${ }^{1}$. Una de las maneras de desenredar la madeja de significaciones adosadas a una tradición es auscultar los sentidos que un espacio político otorga a fechas o eventos históricos singulares. Es pertinente, en este aspecto, la pregunta por los rituales políticos. Por un lado, las conmemoraciones rituales enlazan el presente de los participantes con un pasado particularmente configurado (Claude Rivière, 1988). Luego, en íntima vinculación con lo anterior, dotan a los participantes del rito de un sentido de pertenencia mediante representaciones puestas en común (Darío Macor, 2002). Por último, escenifican jerarquías entre los convocantes y los convocados a la práctica ritual. Las figuraciones jerárquicas no son estáticas. Están sometidas a cambios históricos, políticos y sociales (Marc Augé, 1998).

Este artículo estudia las tradiciones políticas del peronismo entre 1962 y 1966, analizando dos celebraciones capitales del espacio político peronista: el Primero de Mayo y el «17 de Octubre». ${ }^{2}$ La elección de este periodo no es azarosa. Esto años se caracterizaron, de un lado, por una actitud bicéfala de los gobiernos civiles. Mientras los presidentes Arturo Frondizi (1958-1962) ${ }^{3}$ y Arturo Illia (1963-1966) ${ }^{4}$ buscaron integrar a las huestes peronistas al sistema

1. Esta definición se vale de investigaciones como las de Antonio Gramsci [1948] (2003), Hannah Arendt [1954] (2016), Hans Georg Gadamer [1960] (1999), Raymond Williams [1977] (2000), Eric Hobsbawm [1983] (2002) y Gerardo Aboy Carlés (2001).

2. En Conducción Política, Perón señaló que su movimiento tenía solo dos fechas para hacer actos públicos y "pone[r] un millón de hombres en la plaza de Mayo»: el Primero de Mayo y el «17 de Octubre» (Juan Domingo Perón, [1951] (1974): 189).

3. Tras un creciente ciclo de protestas obreras, la autodenominada «Revolución Libertadora» convocó elecciones presidenciales en 1958. Con el apoyo peronista, Frondizi, candidato de la Unión Cívica Radical Intransigente (UCRI), logró la presidencia. Sin embargo, el idílico «romance» con Perón se marchitó cuando las promesas hechas al caudillo no se concretaron. Véase Catalina Smulovitz (1988) para ampliar.

4. Candidato por la Unión Cívica Radical del Pueblo (UCRP) en las elecciones presidenciales del 7 de julio de 1963, Illia logró la presidencia con un $25 \%$ de los votos. El peronismo fue impedido de participar por el veto militar. Sobre el gobierno del «radical del pueblo», se sugiere César Tcach y Celso Rodríguez (2006). 
político a través de los llamados partidos «neoperonistas» ${ }^{5}$, el interregno de José María Guido (1962-1963) ${ }^{6}$ optó, en cambio, por mantener al peronismo fuera del juego institucional. Sin embargo, más allá de estas diferencias, las tres administraciones prohibieron a Juan Domingo Perón su intervención legal en la arena política. Y, del otro, este periodo se distinguió por el papel central que desempeñó el gremialismo. Con las aperturas y cierres de los canales electorales, el sindicalismo de cuño peronista fue obteniendo mayor peso y márgenes de maniobra más amplios a lo largo de los años. Particularmente representativa fue la figura del secretario general de la Unión Obrera Metalúrgica (UOM), Augusto Vandor ${ }^{7}$.

El artículo examina las celebraciones del Primero de Mayo y del «17 de Octubre» a partir de diarios nacionales y provinciales de la Argentina, poniendo especial atención a los sentidos que los peronistas en el país otorgaron a estas fechas. Se quiere estudiar, en este aspecto, las características dadas y sus vínculos con las conmemoraciones llevas a cabo durante el gobierno de Perón. Esta división geográfica de las fuentes utilizadas permitirá ahondar en las particularidades y las semejanzas que tuvieron los rituales políticos realizados a lo largo del país. Ello significa no solo poner el foco en la Capital Federal, sino también en principales ciudades provinciales como Rosario, Córdoba, Santa Fe, San Miguel de Tucumán, para nombrar algunas.

Si, como han mostrado Aníbal Viguera (1991), Mariano Ben Plotkin [1993] (2013) y Daniel James (1995), la figura de Perón fue central en las celebraciones del Primero de Mayo y del «17 de Octubre» en la Argentina durante sus años de gobierno, ¿qué sucedió con sus conmemoraciones tras el quiebre constitucional de $1955 ?^{8}$ ¿De qué forma se vincularon las escenificaciones rituales ensayadas por las huestes peronistas en la Argentina entre 1962 y

5. Así se denominaron los partidos que buscaron hacerse con los votos dejados por el peronismo proscripto desde 1955. El primero y más importante de ellos fue la Unión Popular (UP), formado por los antiguos funcionarios del régimen Rodolfo Tecera del Franco y Atilio Bramuglia. Se sugieren María Arias y Raúl García Heras (1993), y Julio César Melón Pirro (2009) para ahondar.

6. En marzo de 1962, los mandos militares ofrecieron a José María Guido, presidente provisional del Senado, la primera magistratura. Para ampliar sobre las particularidades de su gobierno, véase Daniel Rodríguez Lamas (1997).

7. Para ahondar en su figura, Santiago Senén González y Fabián Bosoer (2009).

8. Tras el golpe de Estado de 1955, Perón se alojó en distintos países. Estuvo brevemente en Paraguay y en noviembre del mismo año se trasladó a Panamá. Entre 1956 y 1958, vivió en la Venezuela de Marcos Pérez Jiménez. Tras la caída del dictador venezolano, Perón se trasladó a República Dominica. Finalmente, en 1960 arribó a España, último destino hasta su retorno a la Argentina el 17 de noviembre de 1972. 
1966 con las organizadas durante el régimen peronista? ¿Cuáles fueron sus elementos de continuidad y de ruptura?

En la primera parte se examinan las conmemoraciones del Primero de Mayo realizadas por el peronismo en el periodo 1962-1966. En los rituales políticos llevados a cabo, se pasó de la nula referencia a Perón y a su movimiento, a un «tono peronista» marcado. Por ello aquí se habla de una «reperonización» del Primero de Mayo. La segunda parte analiza las celebraciones rituales del «17 de Octubre» también entre 1962 y 1966. El hecho de haber sido una fecha capital del régimen peronista no impidió el surgimiento de nuevas significaciones. Esto se corresponde con la caracterización de las tradiciones políticas como recreaciones sobre un pasado a la luz de las vicisitudes demandadas por el presente.

\section{Hacia una «reperonización» del Primero de Mayo}

En la Argentina, los primeros homenajes a los trabajadores muertos en la llamada «Masacre de Haymarket» comenzaron en 1890, organizados por el club socialista alemán Vorwärts. Para Plotkin [1993] (2013), estas manifestaciones se caracterizaron por ser pacíficas, legalistas e incluso festivas. Inicialmente estuvieron asociadas a símbolos patrios, algo que sucedía también en otras partes del mundo. En las primeras celebraciones, el Partido Socialista tuvo un rol fundamental en su organización'. A comienzos de 1900, los anarquistas comenzaron a conmemorar el Primero de Mayo en Argentina. Según Juan Suriano y Luciana Anapios (2011), antes que una fecha festiva, la entendían como una de luto y de dolor. Para finales de la primera década del siglo XX, los actos anarquías eran importantes. Sin embargo, como anota Plotkin [1993] (2013), para 1911 las celebraciones socialistas nuevamente hegemonizaron las llevadas a cabo en el país.

En 1920, el Primero de Mayo se encontraba incorporado a la cultura política argentina. A tal punto, que el «Estado mismo intentaba apropiarse del significado de la celebración» (Plotkin, [1993] 2013: 90). Incluso los sectores nacionalistas comenzaron a sentirse convocados por esta fecha, como señala Mariela Rubinzal (2011). Durante las décadas de los veinte y treinta, concibieron las conmemoraciones del Primero de Mayo como una forma de configurar una identidad obrera nacionalista frente al internacionalismo de las organizaciones marxistas. Los valores patrióticos -y la moral católica- que pregonaban se correspondían con los símbolos que acompañaron las celebraciones del

9. Al respecto, Francisco Reyes (2016) examina la importancia de la fecha en la identidad política socialista en la Argentina. 
Primero de Mayo en el país: la entonación del Himno Nacional -cantado por primera vez en 1936-, y la bandera argentina.

Con la denominada «Revolución de Junio» de $1943^{10}$ se inició un nuevo capítulo. Según Plotkin [1993] (2013), tras el golpe de Estado, Perón buscó unificar el significado y las conmemoraciones del Primero de Mayo. En este proceso, recuerda Viguera (1991), cobró especial relevancia el carácter oficial que el régimen otorgó a la fecha. Las celebraciones de 1947 y 1948 bajo el gobierno peronista incorporaron elementos que se repetirían luego: concentraciones en la Plaza de Mayo, con aval oficial y organizadas por la CGT. Mediante un programa cuidadosamente confeccionado, el Primero de Mayo peronista institucionalizó desde el Estado una celebración que era concebida como una «fiesta del trabajo». Los discursos del secretario general de la CGT, de Perón y de Eva Duarte buscaban remarcar las presuntas diferencias entre las conmemoraciones peronistas y las de antaño (Viguera, 1991). Finalmente, aduce Plotkin [1993] (2013), hacia los últimos años del gobierno, la «peronización» del Primero de Mayo estaba completa. Frente a un pasado aparentemente caracterizado por protestas violentas y manifestaciones de duelo, Perón presentaba las celebraciones «pacíficas»y «patrióticas» bajo su administración.

Si el Primero de Mayo constituyó una de las celebraciones principales del peronismo durante su gobierno ¿qué sucedió en los años posteriores al derrocamiento a Perón en 1955? No existen al momento investigaciones que estudien sus conmemoraciones en este periodo ${ }^{11}$. En las líneas siguientes se examinan los actos del Primero de Mayo que el peronismo celebró entre 1962 y 1966 en las principales ciudades argentinas.

La denominada «Revolución Libertadora» tras el golpe de Estado de 1955 buscó llevar a cabo una «desperonización $»^{12}$. Se trató de un conjunto de medidas que removían los nombres de Perón y de Eva Duarte de toda institución así bautizada, prohibían libros con «contenido peronista» y vedaban la famosa marcha «Los muchachos peronistas». Se intervino, además, la Confederación General del Trabajo (CGT) y se detuvo a ex líderes políticos y sindicales ligados al peronismo ${ }^{13}$. Ello impidió cualquier tipo de recuerdo del Primero de Mayo en el periodo del gobierno militar (1955-1957). Con Frondizi, si bien

10. Así se denominó el golpe de Estado del 4 de junio al presidente Ramón Castillo. Perón fue una de las figuras principales del nucleamiento que lo impulsó. Para ampliar, véase Robert Potash (1986).

11. Laura Ehrlich (2012) no analiza las conmemoraciones del Primero de Mayo en el peronismo luego de 1955. Este artículo complementa algunas de sus ideas.

12. Para ampliar sobre el intento «desperonizador», véase María Estela Spinelli (2005).

13. Gran parte de las medidas prohibitivas y proscriptivas formaron parte del decreto-ley 4151 del 5 de marzo de 1956 (Roberto Baschetti, 2012). 
la persecución a las huestes peronistas disminuyó en intensidad, el quiebre de su relación con el movimiento obrero ${ }^{14}$ y la implementación del Plan de Conmoción Interna del Estado (CONINTES) ${ }^{15}$, dificultaron las conmemoraciones en recuerdo del «Día de los Trabajadores».

El primer día del mes de mayo de 1962 constituyó una fecha importante. Por un lado, debían asumir los candidatos electos en los comicios anulados del 18 de marzo $^{16}$. Y, por el otro, el gobierno de Guido, mediante la introducción del Estado de sitio, prohibió toda manifestación pública. Esta medida no solo alcanzó a la Capital Federal ${ }^{17}$. También se hizo sentir en las provincias ${ }^{18}$. En lo que respecta a dos actores principales del escenario gremial argentino, la Comisión Provisoria de la CGT y las «62 Organizaciones Peronistas» ${ }^{19}$, no elaboraron pronunciamientos a los fines de evitar conflictos con las autoridades. Se temían quitas de personerías gremiales, inhibiciones o detenciones. En estas organizaciones sobrevolaba la misma opinión que expresaba el secretario general del sindicato de la Sanidad, Amado Olmos: «No repetiremos en 1962 el $1 .^{\circ}$ de Mayo de los mártires que dieron origen a esta manifestación histórica», ya que resultaría en un «despliegue de fuerzas [policiales]» por parte del gobierno ${ }^{20}$.

En el año 1963, sí se celebraron actos por el Primero de Mayo. En Capital Federal, por caso, se realizó uno la sede central de la CGT exclusivo para miembros directivos. El principal orador fue su flamante secretario general,

14. Tanto Daniel James (1990) como Alejandro Schneider (2005) examinan las protestas obreras de 1958.

15. Este fue el nombre que recibieron una serie de disposiciones del Poder Ejecutivo que dotaron a las Fuerzas Armadas del poder de intervenir en conflictos políticos internos. El plan estuvo vigente entre marzo del ' 60 y agosto del ' 61 . Para ahondar en las implicaciones del CONINTES, véase Nicolás Damin (2010) y Esteban Pontoriero (2017).

16. El 18 de marzo de 1962 se celebraron elecciones en varias provincias. El peronismo triunfó en Jujuy, Chaco, Misiones, Neuquén, Río Negro, Salta, San Juan y Tucumán. La victoria más resonante sucedió en Buenos Aires, donde resultó electo gobernador el candidato de la UP, Andrés Framini. Ante este escenario, los militares obligaron a Frondizi a intervenir los distritos donde el voto peronista fue mayoritario. El 29 de marzo, ante la negativa del presidente, las Fuerzas Armadas ocuparon el Congreso Nacional y lo detuvieron. Para ampliar sobre estas cuestiones, se sugiere nuevamente Smulovitz (1988).

17. «La prohibición oficial impidió que los trabajadores conmemoraran su día», en Democracia, Buenos Aires, 02/05/62, p. 5.

18. «Una jornada de completa normalidad, sin actos alusivos, fue la del día universal del trabajo», en El Litoral, Santa Fe, 01/05/62, p. 5.

19. Respecto al nacimiento de las «62 Organizaciones Peronistas» y a la actuación de la Comisión Provisoria de la CGT, véase James McGuire (1993) y Schneider (2005).

20. «Tribuna libre. Opinan los dirigentes sindicales. Hoy: Amado Olmos», en Democracia, Buenos Aires, 30/03/62, p. 8. 
José Alonso ${ }^{21}$. Después de un breve racconto de la situación económica del país, remarcó la «total solidaridad e identificación del movimiento obrero», en contra del ejemplo de división y búsqueda de beneficios personales de la administración de Guido $^{22}$. Asimismo, sugirió a los presentes que en la Argentina debía llevarse a cabo una revolución social para «romper con las estructuras que nos asfixian y las trabas que no nos dejan avanzar». ${ }^{23}$

Debe remarcarse, por una parte, que la conmemoración contó con la presencia de representantes del Consejo Coordinador y Supervisor del Peronismo $(\mathrm{CCS})^{24}$, encabezada por su secretario general, Raúl Matera. Éstos fueron los únicos dirigentes políticos presentes ${ }^{25}$. Y, por la otra, cuando finalizaba el acto algunos de los presentes quisieron entonar «Los muchachos peronistas». Sin embargo, no hubo entusiasmo en el público ${ }^{26}$. Las voces fueron rápidamente acalladas «al grito de 'CGT... CGT'». ${ }^{27}$ Aún con la presencia de figuras representativas de las organizaciones políticas del peronismo, la conmemoración desarrollada en Buenos Aires en el '63 se mostró renuente a hacer intervenir elementos alegóricos al movimiento acaudillado por Perón.

No obstante, éstos sí estuvieron presentes en las provincias. Por ejemplo, las organizadas por la CGT local en las ciudades de Rosario y de Córdoba ${ }^{28}$ se caracterizaron por la entonación primero del Himno Nacional Argentino y luego por la colocación de ofrendas florales en homenaje a José de San Martín. Como ya se sugirió, una apuesta del gobierno peronista fue «nacionalizar» y «pacificar» el Primero de Mayo, presentándolo como una muestra cabal del clima de unidad que regía en la Argentina de Perón. Esto es, quitarle cualquier viso de internacionalismo y de carácter virulento a la fecha. Sin embargo, las primeras manifestaciones en Argentina en recuerdo del Primero de Mayo a finales del siglo XIX se asociaron tempranamente a símbolo patrios ¿Por

21. Entre finales de enero y principios de febrero de 1963 sesionó en Capital Federal el Congreso Normalizador de la Confederación. José Alonso, de la Federación de Obreros del Vestido, fue elegido secretario general. Se sugiere James (1990) para ampliar.

22. «Con diversos actos celebróse el Día de los Trabajadores», en La Nación, Buenos Aires, 02/05/63, p. 1.

23. «Llévose a cabo un acto en la CGT», en La Capital, Rosario, 02/05/63, p. 5.

24. Aparecido en 1958, constituyó la segunda institución creada por Perón para suplir la carencia de organización partidaria propia a nivel local y, simultáneamente, disuadir la aparición y afianzamiento de nuevos liderazgos. Para ampliar, véase Julio César Melón Pirro (2014).

25. «Celebró la CGT el 1. ${ }^{\circ}$ de Mayo», en La Voz del Interior, Córdoba, 02/05/63, p. 8.

26. «Con diversos actos celebróse el Día de los Trabajadores», en La Nación, Op. cit.

27. «Llévose a cabo un acto en la CGT», en La Capital, Op. cit.

28. «Realizóse el acto en el local de la CGT», en La Capital, Rosario, 02/05/63, p. 5 y «Solo la paralización total de actividades caracterizó la celebración del $1 .^{\circ}$ de Mayo», en La Voz del Interior, Córdoba, 02/05/63, p. 11, respectivamente. 
qué razón se sugiere que elementos ligados al peronismo estuvieron presentes en las recordaciones de 1963 en Rosario y Córdoba? De un lado, por el carácter «oficial» de la manifestación organizada por CGT. Fue solo a partir del gobierno peronista que la Confederación pudo organizar su primer acto del «Día de los Trabajadores», luego de años de disputar la fecha con los socialistas (Plotkin, [1993] 2013). Y, del otro, por el lugar central que tomó el homenaje a San Martín. Como recuerda Plotkin (1995), el régimen presentó a Perón como el heredero del «Libertador» ${ }^{29}$. Así, en medio de una ampliación de las medidas prohibitivas a través del decreto 2713 de abril de $1963^{30}$, las ofrendas a San Martín pueden ligarse a un recuerdo del pasado peronista, en general, y de Perón, en particular. Estos elementos se mostraron persistentes en los años consecutivos.

Mayo de 1964 encontró a la CGT visiblemente dividida. Desde el lanzamiento del Plan de Lucha ${ }^{31}$ y, concretamente, a partir de las ocupaciones de los lugares de trabajo -actividad que caracterizó a su segunda etapa-, se produjeron tensiones al interior de la Confederación. Esta situación contribuyó a que el Comité Central Confederal decidiera no organizar un acto como el del año anterior. En Capital Federal, la mesa directiva solo llevó flores al monumento a San Martín en el barrio porteño de Retiro ${ }^{32}$. Lo mismo sucedió en Rosario, donde los secretarios generales de los gremios adheridos concurrieron a la plaza San Martín para homenajear al «Libertador». Días antes, en un comunicado, la entidad regional pidió a los trabajadores que se abstuvieran de participar en manifestaciones ${ }^{33}$.

La notoria «peronización» del Primero de Mayo debió esperar un año más. En 1965 la CGT realizó un acto en Capital Federal, en plaza Miserere. Este emplazamiento constituyó uno de los escenarios donde anarquistas, socialistas

29. También Darío Macor (2013) reparó en esta identificación. A partir de la «Declaración de Independencia Económica» de 1947, el régimen presentó a Perón y a San Martín como dos líderes vinculados más allá de sus particulares coyunturas históricas.

30. Profundizando las disposiciones de los decretos $4161 / 56$ y 7165/62, la nueva legislación prohibía la «apología del tirano prófugo [Perón] o del régimen peronista o del partido disuelto... aun cuando no mediare la existencia de una finalidad de afirmación ideológica o de propaganda peronista» (Citado en Catalina Scoufalos, 2005: 32). En noviembre de 1964, bajo el gobierno de Illia, el mencionado decreto, que ya contaba con una desestimación práctica, fue derogado.

31. Se trató de un plan aprobado en el Congreso Normalizador de enero que atravesó cinco etapas entre 1963 y 1965. Para ampliar sobre algunas de sus características, véase James (1990) y Schneider (2005).

32. «Con diversos actos ayer se celebró el Día del Trabajo», en La Nación, Buenos Aires, 02/05/64, p. 10.

33. «Celebró Rosario el Día de los Trabajadores», en La Capital, Rosario, 02/05/64, p. 14. 
y comunistas realizaron sus manifestaciones en Buenos Aires. Asimismo, casi un siglo antes, fue la arena del «Combate de Miserere» en julio de 1807, donde las fuerzas leales al Virreinato del Río de la Plata se reagruparon y se lanzaron contra las tropas inglesas. Sea por haberse desarrollado allí una batalla capital durante la segunda y fallida «invasión inglesa» en el siglo XIX o por haber constituido el escenario que socialistas, anarquistas y comunistas eligieron para realizar sus actos en el XX, Miserere constituye un «lugar de memoria». Es decir, un resto, una «forma extrema bajo la cual subsiste una conciencia conmemorativa en una historia que la solicita, porque la ignora», como lo entiende Pierre Norá ([1992] 2008: 24). Enfatizando más esta relación de que lo que meramente sugiere Laura Ehrlich (2012), este espacio fue jalonado no solo por las remembranzas de las luchas obreras de principios de siglo. También lo estuvo por el portentoso backgroud histórico que el emplazamiento tiene para la memoria política argentina.

Si bien hubo menos público que en actos pasados, el de 1965 en Buenos Aires no contó con su tranquilidad. Antes de los discursos, jóvenes ligados al peronismo rompieron y quemaron banderas y cartelones de grupos comunis$\operatorname{tas}^{34}$. Mientras algunos se trenzaron a golpes, otros cantaban «Perón sí, otro no» $\mathrm{y}$ «A los traidores los vamos a colgar» ${ }^{35}$. Ante estas consignas, un grupo respondió «Alonso, CGT». Sin embargo, sus cánticos languidecieron frente a las vivas a Perón y a su movimiento. Los ánimos estaban tan exasperados que el público arrojó piedras a Alonso ${ }^{36}$. El primero de los disertantes, el ferroviario Narciso Ángel, intentaba hacer uso de la palabra, pero era impedido por la muchedumbre que se aprestaba a cantar «Los muchachos peronistas». Un desconocido incluso tomó el micrófono y pidió un minuto de silencio por Eva Duarte, algo que no había sucedido en actos pasados ${ }^{37}$.

Esto señala algo acerca del tono que tomó la conmemoración capitalina del Primero de Mayo en 1965. Más aún si se repara en que dos de sus oradores principales fueron los gremialistas electos diputados por el peronismo en los comicios legislativos del mes anterior: el sindicalista de los Municipales, Gerónimo Izetta, y el dirigente de la UOM, Paulino Niembro. Mientras el primero adujo que los trabajadores tenían en claro qué querían y necesitaban para «lograr la vuelta de Perón» ${ }^{38}$, para el sindicalista metalúrgico, la «gran

34. «Fue celebrado el 1. ${ }^{\circ}$ de Mayo con diversos actos», en La Nación, Buenos Aires, 02/05/65, p. 1 y 20.

35. «El mitin de Plaza Once», en La Razón, Buenos Aires, 02/05/65, p. 6.

36. «Graves sucesos en el acto de la CGT», en La Capital, Rosario, 02/05/65, p. 10.

37. «El mitin de Plaza Once», en La Razón, Op. cit.

38. Ibíd. 
familia trabajadora» manifestaba a través de la celebración del acto su decisión de «unirse para poner a Perón en el camino del recuentro». El problema político de la Argentina pasaba, en su opinión, por «hacer justicia a este hombre [Perón] que dio la felicidad al pueblo trabajador ${ }^{39}$.

El nombre de Perón volvió a escucharse públicamente en un acto del Primero de Mayo después de mucho tiempo. Asimismo, y con mayor intensidad que en anteriores, elementos alegóricos al peronismo se hicieron presentes. No solo en la reunión celebrada en la Capital Federal. También en las organizadas por la CGT en Rosario y Santa Fe. Desde las gradas, sectores jóvenes vivaron a Perón, pidieron un minuto de silencio por Eva Duarte y entonaron «Los muchachos peronistas $»^{40}$. Sin embargo, entre estos actos y el de Capital Federal mediaba una cuestión no menor. Aquí la nómina de disertantes estaba compuesta por dos sindicalistas que eran al mismo tiempo legisladores nacionales peronistas. Ello suponía, de alguna forma, incorporar al peronismo a los homenajes y, a su vez, subir simbólicamente a Perón al estrado.

Estos procesos sucedían en medio de una compleja situación para la CGT. La reafirmación que recibió la conducción en el Congreso Ordinario «Felipe Vallese» de enero de 1965 condujo, como señala Alejandro Schneider (2005), a que el movimiento obrero organizado se ubicara detrás de las «62 Organizaciones» y de Vandor. Este dirigente fue el gran ganador del malogrado «Operativo Retorno» de diciembre del " $64^{41}$, ubicando a sus laderos Niembro y Izetta en las boletas de la UP en las legislativas de 1965. Sin embargo, incluso con esa victoria, Vandor no podía dejar de hacer referencia a Perón. La «camiseta peronista» seguía siendo una prenda que debía usarse en público, aunque se la despreciara en privado.

Las pujas al interior del movimiento obrero se intensificaron en 1966. A las tensiones desencadenadas entre Alonso y Vandor desde mayo del año anterior $^{42}$, se sumó, en enero del ' 66 , el quiebre de las «62 Organizaciones». Un grupo de 18 sindicatos, comandados por Alonso, se separó de la «Mesa Coordinadora» y formó las «62 Organizaciones de Pie Junto a Perón». Este clima contribuyo a que el Comité Central Confederal no realizara un acto por

39. «Fue celebrado el 1. ${ }^{\circ}$ de Mayo con diversos actos», en La Nación, Op. cit.

40. «Efectuáronse actos alusivos al Día de los Trabajadores», en La Capital, Rosario, 02/05/65, p. 5 y «Con un mitin realizado en plaza de la Bandera la CGT celebró el Día de los Trabajadores», El Litoral, Santa Fe, 02/05/65, p. 5.

41. Este fue el intento frustrado de Perón de retornar a la Argentina a principios de diciembre de 1964. Ariel Hendler (2014) examina los pormenores del episodio.

42. «CGT. Un triste callejón sin salidas», en Confirmado, Año 1, n. ${ }^{\circ} 2$, Buenos Aires, 14/05/65, p. 12. 
el Primero de Mayo y tampoco emitiera un comunicado alusivo ${ }^{43}$. Sin embargo, las regionales sí organizaron sencillas ceremonias. En Rosario, por ejemplo, los dirigentes sindicales depositaron flores en el monumento a San Martín en la plaza del mismo nombre. Además, efectuaron un minuto de silencio «en memoria de los trabajadores caídos en las luchas sindicales» y entonaron las estrofas del Himno Nacional. En su discurso, Héctor Quagliaro, secretario general de la CGT Regional Rosario, subrayó que los trabajadores debían «mantenerse unidos en torno a las organizaciones sindicales $»^{44}$, en clara referencia a los problemas internos que atravesaban al gremialismo argentino en estos años. La colocación de ofrendas florales a San Martín caracterizó también el homenaje de la CGT cordobesa ${ }^{45}$. Sin embargo, el acto contó con abucheos, silbidos y gritos entre organizaciones rivales ${ }^{46}$.

En la Capital Federal los homenajes al Primero de Mayo difirieron respecto a los años anteriores. Al igual que en las ciudades antes mencionadas, no hubo concentraciones callejeras y los actos fueron reducidos. La «Mesa Coordinadora» de las «62 Organizaciones» se congregó plaza Martín Fierro, donde funcionaron hasta la década de los cuarenta los talleres de Pietro Vassena. Escenario de la represión del gobierno de Hipólito Yrigoyen en enero de 1919, que dejó 800 muertos y pasó a ser conocida como la «Semana Trágica $»^{47}$. Allí Paulino Niembro, en nombre de la UOM, recordó a los «mártires obreros». Este espacio fue visitado también por el sector de Alonso. ${ }^{48}$ Sin embargo, su periplo no terminó allí. Depositó las tradicionales flores a San Martín, trasladándose luego a la bóveda de Tomás Perón -abuelo Juan Domingo Perón-y colocando también una corona. Finalmente, en el pequeño homenaje en el sindicato de Calzado, Alonso anunció que había recibido una carta de Perón. En ella, el caudillo aprobaba la resolución final del plenario realizado en la provincia de Tucumán ${ }^{49}$ por las «62 Organizaciones de Pie

43. «Solo la paralización de actividades y actos aislados, jalonaron la fecha», en La Voz del Interior, Córdoba, 02/05/66, p. 9.

44. «Se memoró en nuestra ciudad el Día del Trabajador», en La Capital, Rosario, 02/05/66, p. 9.

45. «Solo la paralización de actividades y actos aislados, jalonaron la fecha», en La Voz del Interior, Op. cit.

46. «Fue celebrado el Día de los Trabajadores», en La Nación, Buenos Aires, 02/05/66, p. 10.

47. Para ampliar sobre estos episodios, Julio Godio (1985).

48. «La celebración del Día del Trabajador», en La Capital, Rosario, 02/05/66, p. 9.

49. Este encuentro contó con la participación de gremios de conocida militancia «antivandorista» como la Federación Obrera Tucumana de la Industria de Azúcar (FOTIA), Sanidad, Textiles, Farmacia, Caucho, Calzado y Tabaco. Schneider (2005) recorre las implicancias para el movimiento obrero argentino del quiebre de las «62 Organizaciones Peronistas». 
Junto a Perón $»^{50}$. Mientras se esperaban estas palabras, en las inmediaciones se repartieron fotos de Perón y de María Estela Martínez, su tercera esposa. Llevaban como leyenda «Con Isabelita.../ Perón está cerquita», en alusión al rol de «delegada personal» de su marido desde su arribo a la Argentina en octubre de $1965^{51}$.

Si al anuncio de la carta y a esta parafernalia que acompañó el acto en el sindicato del Calzado se le agrega el homenaje en el Cementerio de la Chacarita a la familia Perón, puede sostenerse que la apuesta de las «62 Organizaciones de Pie» era imprimirle a la recordación del Primero de Mayo un cariz peronista. Se trataba no solo de homenajes a la familia Perón y de entrega de elementos fotográficos, sino también del anuncio de la posesión de una carta -dispositivo por excelencia de las polémicas peronistas durante los años de la proscripción- ${ }^{52}$ que avalaba al nuevo nucleamiento. Este elemento legitimador le permitió marcar al grupo de Alonso, como señalaba su declaración respecto al Primero de Mayo en De Pie $!^{53}$, que detrás de los pedidos de «libertad» y de «unidad» de los sectores gremiales «vandoristas» se escondía, en verdad, un intento por socavar las resoluciones elaboradas en el plenario de Tucumán. Al estar éstas avaladas por Perón, significaban una afrenta a la autoridad del caudillo ${ }^{54}$.

\section{El «17 de Octubre», las escenas y conflictos del peronismo}

Según Plotkin (1995), Perón redefinió los sentidos del «17 de Octubre» en la sucesivas celebraciones ocurridas durante su gobierno. Cada una de ellas colocó en un lugar aún más central a su figura, desdibujando algunas de las características que el suceso «originalmente» tuvo. Fue perdiendo su carácter conmemorativo, transformándose en un ritual donde el régimen celebraba el vínculo de Perón con su pueblo. Se intentó desligar a la fecha, en definitiva, del «comportamiento festivo y carnavalesco» que tuvo el hecho «original» en 1945 (James, 1995: 112). El proceso tomó dinamismo con el fallecimiento de Eva Duarte en 1952.

Resulta relevante referir un señalamiento de Macor (2013). Desde los años 1948 y 1949 hasta los cincuenta, las celebraciones del «17 de Octubre» en

50. «Fue celebrado el Día de los Trabajadores», en La Nación, Op. cit., p. 5.

51. Ibíd.

52. Silvia Sigal y Eliseo Verón (1988) han reparado en las características del «discurso político por correspondencia» del periodo 1955-1973.

53. De Pie fue el órgano semanal de las «62 Organizaciones de Pie Junto a Perón». Contó con 19 números y se editó entre marzo y julio de 1966. Su director fue José Alonso. Para ampliar sobre el semanario, véase Facundo Carman (2015).

54. «Declaración de las 62. Los trabajadores, el lero de Mayo y la unidad», en De Pie!, Año 1, n. ${ }^{\circ} 8$, Buenos Aires, 03/05/66, p. 10. 
las ciudades de Santa Fe y Rosario tuvieron como ejes centrales a la Capital Federal. Diversas delegaciones encabezadas por las máximas autoridades del distrito eran enviadas hasta allí. Sin embargo, a partir de 1951 se revalorizaron los espacios locales en las conmemoraciones del llamado «Día de la Lealtad» en la provincia. Ello debido al rol adquirido por las regionales de la CGT y por el involucramiento del Poder Ejecutivo provincial en las celebraciones. En sintonía con Plotkin [1993] (2013), Macor (2013) señaló que desde 1951 hasta los momentos finales del gobierno peronista las celebraciones del «17 de Octubre» santafesinas se caracterizaron por el férreo control de la CGT local.

Ahora bien, ¿qué sucedió tras el quiebre constitucional de septiembre de 1955? Se han comentado las medidas prohibitivas que pesaron sobre el peronismo con el arribo de la denominada «Revolución Libertadora». El régimen militar prohibió toda manifestación pública en recuerdo del «17 de Octubre». Incluso se lo quitó de los «feriados nacionales y días no laborales», designación que tenía desde 1946. Desde su prohibición, la fecha comenzó a adquirir nuevos sentidos, muchos de los cuales la acompañaron luego. Para Mónica Gordillo, el «Día de la Lealtad» constituyó una «forma política de resistencia encubierta», de lucha por la memoria reciente y una tentativa por ofrecer una visión alternativa del pasado (2007: 341). En un sentido similar, según Mirta Lobato y Lizel Tornay (2005) se transformó en una ocasión para exteriorizar protestas, con pintadas y estallidos de petardos como sus acciones más características.

Ehrlich (2012) ha trabajado las conmemoraciones del «17 de Octubre» en el periodo 1955-1963. Para la autora, se pueden identificar tres momentos. En el primero, entre los años 55 y 57 , la fecha fue excluida completamente del espacio público. Se produjo luego lo que denomina como un «nuevo patrón geográfico» entre 1958 y 1962. Importantes ciudades provinciales fueron escenarios de actos frente a las prohibiciones en la Capital Federal. Es el caso, por ejemplo, de Rosario, Santa Fe, Paraná, Córdoba y San Miguel de Tucumán. Celebraciones caracterizadas, según esta autora, por la cantidad de oradores, por el Himno Nacional, la marcha «Los muchachos peronistas», el minuto de silencio por Eva Duarte y por la aparición de la juventud del peronismo como un actor diferenciado. El tercer momento que identifica Ehrlich (2012) corresponde al regreso de las celebraciones centrales a la Capital Federal en 1963.

¿Qué relecturas del «17 de Octubre» hicieron los diversos grupos peronistas en el periodo 1962-1966? Asimismo, ¿qué sentidos se mantuvieron «intactos» y cuáles fueron integrados a las celebraciones realizadas? Por último, ¿de qué manera se vincularon esas representaciones con las legadas por la tradición política peronista? En un escenario de fuerte división y disputas con 
el liderazgo de Perón, estas son algunas de las preguntas que guían el análisis de los actos por el llamado «Día de la Lealtad» en los primeros años sesenta considerados.

En 1962, una comisión de la UP encabezada por Rodofo Tecera del Franco se entrevistó con la Jefatura de la Policía Federal solicitando un permiso para un acto en el mítico Luna Park de la Capital Federal. El pedido, sin embargo, no fue concedido ${ }^{55}$. En las provincias, el «17 de Octubre» tampoco pudo ser celebrado. El día 16, la policía de Santa Fe comunicó que se prohibía toda «manifestación o reunión de índole política o gremial en lugares públicos» ${ }^{56}$. En las ciudades de Rosario y Córdoba, recuerda Ehrlich (2012), grupos juveniles intentaron desafiar las prohibiciones con ofrendas florales al Cristo Redentor en el Parque Independencia y una breve reunión en el local de la CGT cordobesa, respectivamente.

El año siguiente la Capital Federal fue el escenario central del llamado «Día de la Lealtad». El lugar elegido, la plaza Miserere. Luego del Himno Nacional, de «Los muchachos peronistas» y del recuerdo a Eva Duarte, Juan Mora, dirigente paraguayo, y los locales Miguel Gazzera, Delia Parodi y Andrés Framini se hicieron presentes en el estrado. Este último era el orador más esperado ${ }^{57}$. Dijo a los presentes que el «17 de Octubre» no simbolizaba solo una fecha para festejar. En esa ocasión, señalaba, «nos vienen a exigir [ustedes] que pongamos en marcha el movimiento, que nos pongamos a la cabeza de las masas». Se aproximaba para el país, según Framini, un «cambio revolucionario de las estructuras», que no tenía nada que ver con «una revolución de esas que hacen los milicos $\aleph^{58}$. Posteriormente se pasó una cinta grabada con un mensaje de Perón. Según el cronista de La Capital, al escuchar su voz, las pocas mujeres presentes abandonaron el acto con sus hijos en brazos $^{59}$. La conmemoración terminó con una dura represión policial ${ }^{60}$.

Al examinar este episodio, Ehrlich (2012) habla de una falta de conexión entre los oradores y el público. De ello deriva dos cuestiones. Una se relaciona con el tipo de fuente, la crónica periodística ¿Hasta qué punto la propia subjetividad del cronista opera en esa lectura de «falta de empatía»? Sin recurrir

55. «Fue denegado el permiso para un acto político», en La Nación, Buenos Aires, 16/10/62, p. 8.

56. «La realización de actos públicos no ha sido permitida», en La Capital, Rosario, 16/10/62, p. 4.

57. «Graves desórdenes en Buenos Aires», en La Voz del Interior, Córdoba, 18/10/63, p. 9.

58. «El mitin de anoche», en La Razón, Buenos Aires, 18/10/63, p. 6.

59. «El peronismo rememoró su fecha máxima», en La Capital, Rosario, 18/10/63, p. 11.

60. «Hubo un tiroteo al término del acto peronista de ayer», en La Nación, Buenos Aires, 18/10/63, p. 7. 
a otras fuentes -por ejemplo, registros fotográficos o filmográficos- es un interrogante sin respuesta. La otra cuestión también puede expresarse como pregunta: ¿dónde está lo fundamental de la conmemoración, en los discursos o en los sentimientos que el público parecía manifestar? Luego de un rodeo, Ehrlich concluye: «[t]al vez lo primordial a destacar sea, en cambio, la realización del acto en sí mismo a pesar (y como mecanismo centrípeto) de tales disputas» al interior del peronismo (2012: 166).

La salida a este segundo predicamento entra en tensión con un señalamiento que le hace a Plotkin [1993] (2013). Según Ehrlich, él desatiende el rol performativo y activante de los mitos y las creencias en los participantes del rito por su insistencia en el carácter manipulativo de los rituales políticos durante el gobierno peronista. Si bien la intención de los actores en el rito y sus efectos constituyen aristas difíciles de conocer, el quedarse con «la realización del acto en sí mismo» no ayuda a resolver la cuestión. El examen histórico debe ser complementado con un estudio acerca de cómo y con qué características fue concebida esa fecha en los diferentes y precisos espacios de tiempo. Los cambios más pequeños hablan de los tópicos y las discusiones que atravesaron, en un espacio y en un tiempo determinado, a las tradiciones políticas peronistas.

Varias ciudades provinciales organizaron también sus celebraciones en 1963. En Rosario, por caso, el lugar elegido fue la plaza San Martín. Una particularidad del acto fue la presencia de José Pardal, dirigente de la Juventud Peronista. Junto a representantes de la rama femenina y de los secretarios generales de la CGT local y de las «62 Organizaciones», Pardal fue uno de los oradores ${ }^{61}$. En la capital santafesina, se destacó también la presencia de la Juventud Peronista en el estrado. En el acto en la plaza de la Bandera, además de los discursos de dirigentes políticos y sindicales, se escuchó el de Lydia Díaz de Gallo, una joven peronista ${ }^{62}$. Distinto fue el panorama en otras dos capitales provinciales, Paraná y Córdoba. En ambos espacios, por un lado, la juventud no gozó del mismo espacio que en los actos antes mencionados. Y, por el otro, la celebración central coincidió con otras desarrolladas simultáneamente. En la capital entrerriana, el acto del Partido Justicialista en la plaza $1 .^{\circ}$ de Mayo coexistió con $\operatorname{dos}^{63}$. Uno convocado por las «62 Organizaciones» locales, ${ }^{64} \mathrm{y}$

61. «El mitin de anoche», en La Razón, Buenos Aires, 18/10/63, p. 6.

62. «El 17 de octubre fue recordado en un acto público», en El Litoral, Santa Fe, 18/10/63, p. 5.

63. «Partidarias», en El Diario, Paraná, 17/10/63, p. 4. El autor agradece a María Josefina Lescano del Archivo General de la Provincia de Entre Ríos por esta referencia.

64. «El mitin de anoche», en La Razón, Op. cit. 
otro por Tres Banderas, un importante partido «neoperonista» provincial ${ }^{65}$. Y, en Córdoba, la conmemoración del PJ local en plaza General Paz coincidió con un acto del Peronismo de Acción Revolucionaria, agrupación dirigida por un joven trabajador cordobés, Marcelo Repezza ${ }^{66}$.

Las celebraciones referenciadas permiten completar un razonamiento de Ehrlich (2012). Según esta autora, la coexistencia de más de un acto en las provincias se relacionaría con la presencia de fuertes partidos neoperonistas. Si bien esto podría derivarse del caso entrerriano, el de Córdoba -o los de Tucumán y San Luis, provincias con estructuras neoperonistas asentadas ${ }^{67}$ pone en tensión este argumento. Más que deberse a la existencia de estos partidos, la dificultad para organizar un acto central se vincula con la situación de profunda división del peronismo local. En este sentido, las divisiones internas no fueron patrimonio exclusivo de los organizadores del acto en la Capital Federal en el año 63, como parece sugerir Erhlich (2012). Esa conflictiva convivencia atravesaba geográficamente a los peronistas a lo largo del país, con las conmemoraciones del «17 de Octubre» como muestra palmaria.

El año siguiente, el acto central fue nuevamente en Buenos Aires. Coincidió con una de las noticias que alertó a los argentinos desde que fue lanzada: el posible regreso de Perón a la Argentina. En 1964 en plaza Miserere se esperaba por Framini. Al referirse a los factores de poderes políticos, económicos y militares, dijo que «el peronismo tendía una mano, sin rencores y con ánimos conciliadores», en el tono en que Perón pergeñaba su campaña retornista. Sin embargo, hizo también una advertencia: «si no atienden esta oferta, serán responsables de lo que acontezca». Ante esto, el público alzó su voz pidiendo «leña, leña» y «al paredón, al paredón ${ }^{68}$. El acto terminó de forma similar al celebrado el año anterior: la policía reprimió a los manifestantes cuando quisieron tomar Av. Rivadavia ${ }^{69}$.

El júbilo y la algarabía del público hacia Framini, y la desaprobación ante las palabras de Vandor -al que le gritaban « Ya lo vas a traicionar a Perón vos!»-70 permiten comprender algo del ambiente que caracterizó al peronismo en estos

65. «Hará un acto la Unión Popular», en La Capital, Rosario, 17/10/63, p. 5.

66. «Acto celebrando aniversario del 17 de octubre habrá esta tarde», en La Voz del Interior, Córdoba, 17/10/63, p. 13 y «Acto hará hoy recordando el 17 de octubre el PAR», en La Voz del Interior, Córdoba, 17/10/63, p. 11.

67. «El mitin de anoche», en La Razón, Op. cit.

68. «El peronismo realizó ayer su acto en la Plaza Once», en La Nación, Buenos Aires, 18/10/64, p. 20.

69. «Celebró su día el peronismo. Al término del acto de Plaza Once hubo incidentes», en El Mundo, Buenos Aires, 18/10/64, p. 6.

70. «El peronismo realizó ayer su acto en la Plaza Once», en La Nación, Op. cit. 
años. Estas gestualidades hablan nuevamente de las profundas divisiones en las dirigencias peronistas y de la desconfianza que inspiraban algunos. Ni la victoria aplastante de Vandor en las elecciones internas del peronismo en julio de $1964^{71}$, ni tampoco su rol principal en la Comisión Pro Retorno de Perón entre agosto y septiembre del mismo año ${ }^{72}$, bastaron para suscitar en las huestes la confianza que depositaba en él el viejo caudillo, con los sucesivos viajes y misiones de hombres y mujeres de confianza de Vandor a Madrid.

Trasladando la mirada a las provincias, las conmemoraciones organizadas distaron del clima de la Capital Federal ${ }^{73}$. En Rosario, el PJ local y la regional de las «62 Organizaciones» convocaron a un acto en plaza San Martín. De forma idéntica al año anterior, los oradores representaron a cada una de las ramas que conformaban al peronismo: la masculina, la femenina, la gremial y la juventud ${ }^{74}$. Sin disturbios, los manifestantes se retiraron en tranquilidad. Similarmente sucedió en la capital provincial. En plaza de La Bandera, el acto organizado por el PJ santafesino convocó a más de 2500 personas $^{75}$. La conmemoración se caracterizó por los numerosos oradores ${ }^{76}$. En Córdoba la participación en el acto fue escasa, con las lluvias disuadiendo a los manifestantes a acercarse a plaza General Paz. Sin embargo, las condiciones meteorológicas no eran totalmente responsables del poco público. En San Francisco, ciudad del noreste cordobés, el buen clima y la «profunda e intensa propaganda» de los días previos no fueron suficientes para colmar el acto. Tanto fue así que «uno de los oradores, representante de diversos gremios, tuvo palabras de amargo sabor por la falta de entusiasmo de la masa y su escasísima presencia $»^{77}$.

Según Plotkin [1993] (2013), el peronismo centralizó y homogenizó las celebraciones del «17 de Octubre» durante sus años de gobierno. Este proceso incluso quitó un elemento que caracterizó las primeras conmemoraciones

71. En ellas se enfrentaron candidatos de Vandor y de Framini, resultando vencedores los apadrinados por el primero. Tras su derrota, Framini abandonó las «62 Organizaciones Peronistas». Melón Pirro (2014) reconstruye el enfrentamiento entre vandoristas y fraministas.

72. Se trató de un organismo encargado de conducir las tareas para el regreso de Perón pautado para 1964. Para ampliar, véase Norberto Galasso (2016).

73. A distancia del año anterior, no se registraron actos en Entre Ríos, Tucumán y San Juan. Ello se debió a las «heridas» que dejó el proceso de reorganización interna del peronismo a mitad de 1964.

74. «Culminó en disturbios una concentración peronista», en La Capital, Rosario, 18/10/64, p. 7.

75. «Partido Justicialista. Los asistentes a un acto», en El Litoral, Santa Fe, 20/10/64, p. 5.

76. «Culminó en disturbios una concentración peronista», en La Capital, Op. cit.

77. «No pudo realizarse ayer el anunciado acto justicialista», en La Voz del Interior, Córdoba, 18/10/64, p. 10. 
de la fecha: los desórdenes y actos vandálicos, con los jóvenes de Alianza Liberadora Nacionalista como sus grandes protagonistas ${ }^{78}$. En definitiva, rituales tan centralizados en el Estado -y en la persona de Perón-y homogéneos en su significado como libre de conflictos en las calles. En 1964, como se precisó, el clima de orden solo caracterizó a las celebraciones del «17 de Octubre» en las provincias. Algunas incluso «repitieron» ese aspecto centralizado que tuvieron las conmemoraciones durante el régimen peronista. Los actos en Capital Federal se destacaron, en cambio, por las interrupciones constantes a los oradores y por los enfrentamientos entre los manifestantes y la policía. De esto puede concluirse que la escenificación de la unidad, atravesada por agudas fisuras, no logró apoderarse de las huestes peronistas que se acercaban a Miserere para recordar la «gesta de octubre».

La situación de violencia en la Capital Federal no amainó en 1965. El 17 de octubre la Policía Federal canceló su autorización para el acto en el Parque de los Patricios. Se hablaba de no «actualizar causas de enfrenamiento superadas» y de «menoscabar el clima de respeto recíproco ${ }^{79}$. Los primeros días del mes había llegado a Buenos Aires, para asistir a los festejos de la fecha máxima del peronismo, María Estela Martínez. Su visita, empero, no fue bien recibida por todos. Las manifestaciones en su contra derivaron en grescas entre grupos peronistas y «antiperonistas» en las calles porteñas ${ }^{80}$. El gobierno nacional aprovechó esta situación para cancelar la celebración de los veinte años del llamado «Día de la Lealtad $»^{81}$. Ello ocasionó algunos disturbios en el que iba a ser el escenario de la celebración en la madrugada del 17. Se organizó un operativo policial especial en edificios públicos y vías de entrada a la Capital Federal $^{82}$.

78. Para ampliar sobre esta organización ligada a nacionalismo «de derecha», véase Hernán Capizzano (2013).

79. «La resolución», en La Nación, Buenos Aires, 17/10/65, p. 6.

80. Galasso (2016) desarrolla los incidentes y los movimientos de María Estela Martínez en el mes de octubre de 1965.

81. Con la excepción de los de Rosario, Santa Fe y San Miguel de Tucumán, la mayoría de los actos preparados por los veinte años del «17 de Octubre» corrieron con la misma suerte que el porteño. Policía de la Provincia de Buenos Aires, Archivo y fichero, Mesa Referencias, «Actos 17 de octubre - 1965», Legajo n. ${ }^{\circ}$ 10777, copia proporcionada por el Archivo de la Comisión Provincial por la Memoria, La Plata, Buenos Aires, Argentina, folios 169-173.

82. «Disturbios en Parque de los Patricios», en La Voz del Interior, Córdoba, 18/10/65, p. 7. 
Distinto fue nuevamente el panorama en las provincias. Haciendo a un lado los pequeños incidentes ocurridos en Córdoba por la prohibición de $\operatorname{actos}^{83}$, un clima de tranquilidad caracterizó a los celebrados en las ciudades del llamado «Interior» del país ${ }^{84}$. En Rosario se eligió de nuevo a la plaza San Martín como escenario. Gran cantidad de público concurrió con carteles, banderas argentinas, «estrellas federales», «tacuaras», y fotos de Perón y de Eva Duarte. La lista de oradores no difirió de las anteriores, con espacios para sectores gremiales, políticos y juveniles. Para uno de los disertantes, Francisco Amoedo, miembro del PJ santafesino, peronistas y militares estaban cercanos «física y espiritualmente», unidos por «lazos indestructibles», caracterización similar a la que Perón no dejó de referir en sus años de gobierno ${ }^{85}$. «Les decimos a los militares -vociferó Amoedo- que tienen que hacer la revolución hoy o la harán los comunistas antes». El público se retiró coreando «Revolución», «Ni yanquis ni rojos, argentinos» $\mathrm{y}$ «Aquí están, estos son, los fusiles de Perón ${ }^{86}$. En la ciudad de Santa Fe el peronismo organizó su celebración del «17 de Octubre» en la plaza de la Bandera. A distancia del acto en Rosario, solo hablaron dirigentes partidarios y gremiales locales. Ninguno en representación de la juventud peronista. El acto estuvo custodiado por efectivos policiales ${ }^{87}$.

Particular fue la situación en San Miguel de Tucumán. La conmemoración estuvo precedida por tensiones en la Comisión Provincial Organizadora, específicamente entre el Movimiento de la Juventud Peronista de la III Zona, y los partidos Unión Popular y Acción Provinciana ${ }^{88}$. Otra peculiaridad estuvo dada por los múltiples homenajes que antecedieron al día 17: un acto en la histórica Casa de Tucumán, otro en la CGT local y una visita a orfelinatos y hospitales ${ }^{89}$. La conmemoración en el microcentro tucumano se caracterizó también por las interrupciones de los jóvenes peronista a los oradores. La celebración tuvo su momento más álgido con el discurso del diputado nacional Fernando Riera. Contagiado por la efervescencia de los jóvenes, el legislador aseguró que el

83. «Prohibieron actos peronistas hoy en Capital e interior», en La Voz del Interior, Córdoba, 17/10/65, p. 10 y «Transcurrió en orden la celebración en el Interior», en La Razón, Buenos Aires, 18/10/65, p. 4.

84. «Clima tranquilo en el interior», en La Voz del Interior, Córdoba, 18/10/65, p. 8.

85. Para ampliar sobre el vínculo Fuerzas Armadas-pueblo en el imaginario de Perón, véase León Rozitchner [1985] (2012).

86. «Transcurrió en orden la celebración en el Interior», en La Razón, Op. cit.

87. «Llévose a cabo anoche en forma tranquila el acto peronista», en El Litoral, Santa Fe, 18/10/65, p. 4.

88. «Justicialista», en La Gaceta, Tucumán, 10/10/65 y «Protestas de agrupaciones del peronismo contra la comisión del 17 de Octubre», en La Gaceta, Tucumán, 13/10/65, p. 8.

89. «Los oradores del acto peronista del 17 de Octubre», en La Gaceta, Tucumán, 16/10/65, p. 5. 
peronismo debía «tomar las armas de [la] lucha... [donde] el pueblo tiene que vencer o morir ${ }^{90}$. Riera adujo que el general Juan Carlos Onganía podía ser presidente si el peronismo le daba su respaldo ${ }^{91}$.

Los acontecimientos de 1965 parecieron reiterar la dicotomización geográfica de las celebraciones del «17 de Octubre» que señala Ehrlich (2012) durante el frondizismo. Los actos prohibidos en la Capital Federal tuvieron su contraparte con los organizados en las principales ciudades provinciales. Asimismo, parecía repetirse la situación que caracterizó a los años de Frondizi: la «espada de Damocles» de un golpe militar ${ }^{92}$. Como se apreció en los actos de Rosario y Tucumán, el quiebre constitucional vía intervención de las Fuerzas Armadas asemejaba ser una posibilidad tan real como anhelada por las dirigencias peronistas. Finalmente, este deseo encontraba cierta correspondencia con la intensa confrontación de los discursos por el «17 de Octubre» referenciados. Tono que, por otro lado, sintetizó un documento del bloque de Diputados Nacionales peronistas tras la prohibición del acto central en Capital Federal: «Nosotros queremos la paz, pero si ellos [Illia y su gobierno] quieren la guerra, también la tendrán; devolveremos golpe por golpe y vida por vida $»^{93}$.

La intervención militar sobrevino finalmente el 28 de junio de 1966. La autodenominada «Revolución Argentina» al mando del general Juan Carlos Onganía destituyó al presidente Illia, disolviendo el Congreso, la Corte Suprema de Justicia y todos los partidos políticos. Como recuerda César Tcach (2007), el régimen fue apoyado explícitamente por organizaciones patronales y la prensa. En cuanto al sindicalismo, la asistencia de Vandor y de Alonso a la asunción del presidente de facto señala el apoyo del gremialismo al nuevo gobierno. Perón también manifestó su beneplácito por el derrocamiento de Illia y sus ilusiones con la llegada al poder de Onganía ${ }^{94}$. Sin embargo, estas iniciales esperanzas se irían diluyendo en los meses siguientes.

En lo que refiere específicamente a la conmemoración del «17 de Octubre», el régimen militar prohibió toda manifestación en el país. Ante la presunta organización de un acto en plaza Miserere, se reforzó la seguridad en sus inmediaciones y se vedó la reunión de personas ${ }^{95}$. La jornada, según un informe de la Policía Federal, se caracterizó por algunos incidentes en las calles porte-

90. «Se realizó ayer el acto de los peronistas», en La Gaceta, Tucumán, 18/10/65, p. 6.

91. «Transcurrió en orden la celebración en el Interior», en La Razón, Op. cit.

92. Entre 1958 y 1962, el gobierno de Frondizi tuvo 32 «planteos» militares.

93. «Bloque justicialista», en La Capital, Rosario, 16/10/65, p. 17.

94. «Perón: tres horas con Primera Plana», en Primera Plana, Año 3, n. ${ }^{\circ}$ 183, Buenos Aires, 30/06/66, p. 7.

95. «Vigilancia policial en sectores de Bs. Aires», en El Litoral, Santa Fe, 17/10/66, p. 2. 
ñas y por una «absoluta normalidad» en las provincias ${ }^{96}$. Al igual que en los primeros años de la «Liberadora», a comienzos de este otro gobierno militar, la celebración máxima del peronismo era prohibida en toda la Argentina. Volvía a ser una conmemoración clandestina.

\section{Conclusiones}

Este artículo analizó los sentidos que el peronismo entre los años 1962 y 1966 otorgó a dos fechas capitales de su espacio político, el Primero de Mayo y el «17 de Octubre». Entendiendo a las tradiciones políticas como un conjunto selectivo e inventado de valores y prácticas que, transmitidas desde el pasado y releídas desde el presente, informan a los miembros de un grupo sobre los modos en que puede pensar, actuar y sentir, se examinaron las celebraciones rituales en la Capital Federal y las principales ciudades provinciales. Los rituales políticos enlazan a los participantes con el pasado, les dan sentido de pertenencia y a su vez escenifican jerarquías.

¿Qué sentidos hallados en los actos peronistas del Primero de Mayo y del «17 de Octubre» en el periodo 1962-1966 deben ser señalados? De un lado, en lo que refiere a la primera fecha, el rol de la reunificada CGT en la organización. A partir de ello podría decirse que se continuaba con el lugar central que el régimen peronista dio a la Confederación en los actos. Asimismo, debe mencionarse la colocación de ofrendas florales a José de San Martín y la entonación del Himno nacional, actividades que caracterizaron varias de las conmemoraciones examinadas en la Capital Federal y en las provincias. Aquí se mostraba persistente el motivo que esgrimió el nacionalismo en las décadas de 1920 y 1930 en la Argentina: nacionalizar una fecha a la que se ligaba con tendencias internacionalistas. El gobierno de Perón apeló a estas ideas cuando diferenció el Primero de Mayo peronista -pacífico, patriótico y alegre- frente a los anteriores -violentos, foráneos y de luto-. Sin embargo, lejos de este anhelo, los años considerados en este artículo mostraron que dos cuestiones intervenían en el agrietamiento de esta idílica visión. En primer lugar, la injerencia del peronismo y de sus huestes proscriptas. Si la CGT añoraba retornar, amparándose en el peso específico del gremialismo, a la situación de principios de los años cuarenta para el movimiento obrero organizado, el «fantasma peronista» acosaba sus fantasías. Para 1965, en Capital Federal, Rosario y Santa

96. Policía de la Provincia de Buenos Aires, Archivo y ficheros, Mesa Referencia, «Actos relacionados con el '17 de octubre año 1966'», Legajo 10777, copia proporcionada por el Archivo de la Comisión Provincial de la Memoria, La Plata, Buenos Aires, Argentina, folios 254-290. 
Fe el peronismo pareció retomar su lugar en las celebraciones del Primero de Mayo. Y, en segundo lugar, las divisiones internas del movimiento obrero tras a la «apuesta neoperonista» de Vandor. Si su hegemonización del gremialismo condujo a una fisura considerable en la CGT, la intención de disputarle a Perón su liderazgo fraccionó al sindicalismo peronista, como lo atestigua el quiebre de las «62 Organizaciones Peronista» en 1966.

Y, del otro, la organización de las conmemoraciones del «17 de Octubre» incumbió a los hombres fuertes del peronismo, muchos de los cuales eran dirigentes gremiales. A este respecto, una particular configuración geográfica se dibujó en las celebraciones durante el periodo considerado en este artículo. Mientras en los actos en Rosario y Santa Fe la juventud tuvo un lugar entre los oradores, en la Capital Federal, Córdoba, Paraná y Tucumán el estrado únicamente correspondió a dirigentes gremiales y políticos. Allí los jóvenes peronistas solo podían manifestarse entre el público, no pocas veces con interrupciones y actos violentos. Estas características «virulentas» desentonaban en comparación con las celebraciones del llamado «Día de la Lealtad» durante el gobierno peronista. Tan importante como su ajustado programa eran las pacíficas demostraciones del vínculo que aparentemente tenían Perón y su pueblo. Entre los años 1962 y 1966, en contrapartida, la rigurosa lista de oradores y gestualidades -el Himno Nacional, la marcha «Los muchachos peronistas» y el minuto de silencio por Eva Duarte- no se correspondían con el clima de violencia que caracterizó muchos de los actos considerados. Por último, debe verse la intempestiva aparición de la juventud como una suerte de disputa a la jerarquía «tradicional» de los rituales políticos del «17 de Octubre» de los años cuarenta y cincuenta. Los elementos juveniles solicitaban no solo ser reconocidos como actores legítimos dentro del movimiento, sino también «inclinarlo» hacia una «revolución» que juzgaban tan necesaria como inminente. Por estas cuestiones las alocuciones de Framini eran recibidas tan efusivamente por los participantes de los actos capitalinos. Hablaba en el tono en que estos sectores jóvenes entendían la política del peronismo para los primeros sesenta: la «lucha» y la «revolución», cualesquiera sean sus sentidos.

Ahora bien, ¿qué marcan en términos de tradiciones políticas las celebraciones abordadas en este artículo? Por una parte, la persistencia de tópicos articulados por el peronismo durante su gobierno. Las tradiciones son relecturas sobre el pasado, pero elaboradas desde el presente. Piénsese, por caso, en la rigurosa organización, en el rol de la CGT y en la intervención de elementos patrióticos y partidarios. Y, por la otra, que esos temas no se libran de transformaciones cuando son «traídos» al presente. Esa traslación actualiza sus aristas fundamentales. Ello es perceptible, por ejemplo, en el tono en el 
que los oradores planteaban su disputa con el gobierno de Illia: una lucha por la «revolución». Fechas con nacimientos espacial y temporalmente distintos, y con desenvolvimiento desiguales, marcadas por la intervención del gobierno peronista. El artículo se preguntó por las dinámicas de estas celebraciones ligadas a la tradición política del peronismo cuando Perón y su movimiento naufragaron entre el exilio, la proscripción y la persecución.

\section{Bibliografía}

ABOY CARLÉS, Gerardo (2001). Las dos fronteras de la democracia argentina. Rosario: Homo Sapiens.

ARENDT, Hannah [1954] (2016). Entre el pasado y el futuro. Buenos Aires: Ariel. ARIAS, María y GARCÍA HERAS, Raúl (1993). Carisma disperso y rebelión: los partidos neoperonistas. Samuel Amaral y Mariano Ben Plotkin (Comp.) Perón del exilio al poder (95-125). Buenos Aires: Cántaro.

AUGÉ, Marc (1998). Hacia una antropología de los mundos contemporáneos. Barcelona: Gedisa.

BASCHETTI, Roberto (2012). Documentos de la Resistencia Peronista. Vol I y II. Buenos Aires: De la Campana.

CAPIZZANO, Hernán (2013). Alianza Liberadora Nacionalista. Historia y crónica (1935-1953). Buenos Aires: Memoria y Archivo.

CARMAN, Facundo (2015). El poder de la palabra escrita. Buenos Aires: Biblioteca Nacional.

DAMÍN, Nicolás (2010). Plan Conintes y Resistencia Peronista. 1955-1963. Buenos Aires: Instituto Nacional Juan Domingo Perón.

EHRLICH, Laura (2012). Intransigentes, duros y revolucionarios. Variaciones en la cultura politica peronista entre 1955 y 1963 (Tesis doctoral). Facultad de Filosofía y Letras. Universidad de Buenos Aires, Argentina.

GADAMER, Hans-Georg [1960] (1999). Verdad y método I. Salamanca: Sígueme.

GALASSO, Norberto (2016). Perón: Exilio, resistencia, retorno y muerte. 1955-1974. Buenos Aires: Colihue.

GODIO, Julio (1985). La Semana Trágica. Buenos Aires: Hyspamerica.

GORDILLO, Mónica (2007). Protesta, rebelión y movilización: de La Resistencia a la Lucha Armada, 1955-1973. Daniel James (Dir.) Nueva Historia Argentina. Violencia, proscripción y autoritarismo (1955-1976). Tomo IX (329-380). Buenos Aires: Sudamericana.

GRAMCSI, Antonio [1948] (2003). El materialismo histórico y la filosofía de Benedetto Croce. Buenos Aires: Nueva Visión.

HENDLER, Ariel (2014). 1964. Historia secreta de la vuelta frustrada de Perón. Buenos Aires: Planeta. 
HOBSBAWN, Eric [1983] (2002). Introducción: la invención de la tradición. Eric Hobsbawn y Terence Ranger (Eds.). La invención de la tradición (7-21). Barcelona: Crítica.

JAMES, Daniel (1990). Resistencia e integración. Buenos Aires: Sudamericana.

JAMES, Daniel (1995). 17 y 18 de Octubre de 1945. El peronismo, la protesta de masas y la clase obrera argentina. Juan Carlos Torre (Comp.). El 17 de Octubre de 1945 (83-129). Buenos Aires: Ariel.

LOBATO, Mirta Zaida y TONAY, Lizel (2005). La política como espectáculo: imágenes del 17 de octubre. Santiago Senén González y Germán Lerman (Comp.). El 17 de octubre de 1945. Antes, durante y después (221-239). Buenos Aires: Lumiere.

MACOR, Darío (2002). Elecciones, rituales y conmemoraciones en la construcción de la unanimidad peronista, Santa Fe, Argentina, 1946-1955. História Unisinos, 5(4), 205-241.

MACOR, Darío (2013). Representaciones colectivas en los orígenes de la identidad peronista. Revista de Historia, 14, 1-18.

MARX, Karl [1852] (2003). El 18 Brumario de Luis Bonaparte. Buenos Aires: Prometeo.

MCGUIRE, James (1993). Perón y los sindicatos: la lucha por el liderazgo peronista. Samuel Amaral y Mariano Ben Plotkin (Comp.) Perón del exilio al poder (171-219). Buenos Aires: Cántaro.

MELÓN PIRRO, Julio César (2009). El peronismo después del peronismo. Buenos Aires: Siglo XXI.

MELÓN PIRRO, Julio César (2014). Normalización partidaria en tiempos de proscripción. El peronismo entre 1963 y 1965. Julio César Melón Pirro y Nicolás Quiroga (Comp.). El peronismo y sus partidos (149-168). Rosario: ProHistoria. NORÁ, Pierre [1992] (2008). Les lieux de la mémoire. Montevideo: Trilce.

PERÓN, Juan Domingo [1951] (1974). Conducción Política. Buenos Aires: Secretaría Política de la Presidencia de la Nación.

PLOTKIN, Mariano Ben [1993] (2013). Mañana es San Perón. Buenos Aires: EDUNTREF.

PLOTKIN, Mariano Ben (1995). Rituales políticos, imágenes y carisma: La celebración del 17 de Octubre y el imaginario peronista 1945-1951. Juan Carlos Torre (Comp.). El 17 de Octubre de 1945 (171-217). Buenos Aires: Ariel.

PONTORIERO, Esteban (2017). La seguridad interna como "teatro de guerra»: estado de excepción y contrainsurgencia en la Argentina (1955-1976) (Tesis doctoral). Instituto de Altos Estudios Sociales, Universidad Nacional de San Martín, Argentina.

POTASH, Robert (1986). El Ejército y la política en la Argentina. Tomo I. 1928-1945. De Yrigoyen a Perón. Buenos Aires: Hyspanamerica. 
REYES, Francisco (2016). Identidades militantes. Partido, rituales políticos y Nación en los orígenes del radicalismo y el socialismo argentinos (1890-1912) (Tesis doctoral). Facultad de Ciencia Política y Relaciones Internacionales. Universidad Nacional de Rosario, Argentina.

RIVIÈRE, Cluade (1988). Les liturgies politiques. París: Presses Universitaires de France. https://doi.org/10.3917/puf.rivie.1988.01

RODRÍGUEZ LAMAS, Daniel (1997). La presidencia de José María Guido. Buenos Aires: CEAL.

ROZITCHNER, León [1985] (2012). Perón: entra la sangre y el tiempo. Lo inconsciente y la política. Buenos Aires: Biblioteca Nacional.

RUBINZAL, Mariela (2011). ¡A ganar las calles! Movilizaciones nacionalistas en el período de entreguerras. Mirta Zaida Lobato (Ed.). Buenos Aires. Manifestaciones, fiestas y rituales en el siglo XX (129-146). Buenos Aires: Biblos

SCHNEIDER, Alejandro (2005). Los compañeros. Trabajadores, izquierda y peronismo. 1955-1973. Buenos Aires: Imago Mundi.

SCOUFALOS, Catalina (2005). El decreto 4161. La batalla por la identidad (Tesis de licenciatura). Facultad de Filosofía y Letras. Universidad de Buenos Aires, Argentina.

SENÉN GONZÁLEZ, Santiago y BOSOER, Fabián (2009). Saludos a Vandor. Vida, muerte y leyenda de un Lobo. Buenos Aires: Vergara.

SIGAL, Silvia y VERÓN, Eliseo (1988). Perón o muerte. Buenos Aires: Hyspamerica.

SMULOVITZ, Catalina. (1988). Oposición y gobierno: los años de Frondizi. Buenos Aires: CEAL.

SPINELLI, María Estela (2005). Los vencedores vencidos: el antiperonismo y la «Revolución Libertadora». Buenos Aires: Biblos.

SURIANO, Juan y ANAPIOS, Luciana (2011). Anarquistas en la ciudad de Buenos Aires (1890-1930). Mirta Zaida Lobato (Ed.). Buenos Aires. Manifestaciones, fiestas y rituales en el siglo XX (77-100). Buenos Aires: Biblos.

TCACH, César (2007). Golpes, proscripciones y partidos políticos. Daniel James (Dir.) Nueva Historia Argentina. Violencia, proscripción y autoritarismo (19551976). Tomo IX (18-62). Buenos Aires: Sudamericana.

TCACH, César y RODRÍGUEZ, Celso (2006). Arturo Illia: un sueño breve. Buenos Aires: EDHASA.

VIGUERA, Aníbal (1991). El Primero de Mayo en Buenos Aires, 1890-1950: evolución y usos de una tradición. Boletín del Instituto de Historia Argentina y Americana «Dr. E. Ravignani», 3, 53-79.

WILLIAMS, Raymond [1977] (2000). Marxismo y literatura. Barcelona: Península. YERUSHALMI, Yosef Hashim (1989). Los usos del olvido. Buenos Aires: Nueva Visión. 